\title{
Endangered birds of old growth forests in the Pirin National Park, SW Bulgaria: habitat preferrences, distribution and population sizes in 2001-2019
}

Ohrozené vtáky pralesov v Národnom parku Pirin, JV Bulharsko: habitatové preferencie, rozširenie a vel'kost' populácií v rokoch 2001-2019

\section{Petar Shurulinkov ${ }^{1}$, Andrey Ralev ${ }^{2}$, Petko Tzvetkov ${ }^{2}$, Kostadin ValcheV ${ }^{2}$, Girgina Daskalova ${ }^{1}$, Simeon Arangelov ${ }^{2}$, Rumen Kolchagov ${ }^{3}$, Ivan Hristov ${ }^{2}$ \& Petar Dimov ${ }^{4}$}

\footnotetext{
${ }^{1}$ National Museum of Natural History - Sofia, Bulgarian Academy of Sciences, Tsar Osvoboditel, 1, 1000 Sofia, Bulgaria; e-mail: p.shurulinkov@gmail.com

${ }^{2}$ Balkani Wildlife Society, Dragan Tsankov str., 8, 1164 Sofia, Bulgaria

3"Rila" National Park, Bistritsa str., 12 B, 2700 Blagoevgrad, Bulgaria

${ }^{4}$ Institute of Biodiversity and Ecosystem Research, Bulgarian Academy of Sciences, Tsar Osvoboditel, 1, 1000 Sofia, Bulgaria
}

\begin{abstract}
Actual status, distribution, numbers and threats for four forest bird species - Tengmalm's Owl (Aegolius funereus), Pygmy Owl (Glaucidium passerinum), Three-toed Woodpecker (Picoides tridactylus), and Capercaillie (Tetrao urogallus) were studied in the territory of the Pirin National Park, Bulgaria, in the years 2001-2002 and 2019. For the owls, we used night line transect, 2-5 km in length, with acoustic imitation of species calls (henceforth playback) at each 500 (700) m (38 points in 2001-2002, 80 points in 2019). Daytime line transects, 2-5 km in length, were used for counting woodpeckers and Pygmy Owl. In Capercaillie counts, we searched for tracks in the snow, excrements or feathers. GIS analyses were applied for visualization of habitat association and distribution patterns of the studied species. The numbers and distribution of these species were compared between the two study periods and with existing data from previous studies. In 2019 a total of 29 occupied territories of Tengmalm's Owls, 20 territories of Pygmy Owls, 2 territories of Three-toed Woodpeckers and 16 leks of Capercaillies were found. Decrease in numbers was detected for Tengmalm's Owl (-30.4\%) and Capercaillie. These species showed also different spatial pattern of presence between the two study periods. Three-toed Woodpecker population in Pirin NP is very small, not exceeding 10-15 pairs. Pygmy Owl was recorded for the first time during the breeding period in the National Park. The reasons for the differences between the two study periods were discussed. The results indicate some threats (ski tourism development, disturbance by people, sanitary cuttings, etc.) for these birds and can be used for improving the spatial planning of human activities in Pirin NP.
\end{abstract}

Key words: forest birds, habitat, population size, limiting factors, line transect method

\section{Introduction}

The Pirin National Park (henceforth Pirin NP) is an IUCN Category II protected territory situated in the northern part of Pirin Mt. It protects unique endemic and sub-endemic forests of Macedonian Pine (Pinus peuce) and Bosnian Pine (Pinus heldreichii). Logging in the national park is limited to sanitary cutting and thinning mostly for the needs of local people. A high 
number of endemic and relict species of plants and animals live in Pirin NP - 399 endemics and 267 relicts (Project for creation of Management Plan of Pirin NP 2014-2023). Among the birds the main and most important subject of protection are endangered relict forest species such as Three-toed Woodpecker (Picoides tridactylus), Capercaillie (Tetrao urogallus), Tengmalm's Owl (Aegolius funereus) and Pygmy Owl (Glaucidium passerinum). This group of species is the object of the present study. Their status and distribution were studied since the mid-20 $0^{\text {th }}$ century together with avifauna of Pirin Mt. (Simeonov 1975), but these birds remained insufficiently studied and some of them $(A$. funereus, $G$. passerinum) were not found as breeding birds or breeding was only assumed for Tengmalm's Owl (Baumgart 1987, Beron 2002). In the period 2001-2002 an ornithological survey of all forest birds was undertaken as a part of the preparation of management plan of Pirin NP and the first more precise results were presented (Shurulinkov \& Stoyanov 2003, Shurulinkov et al. 2003). However, the sites of rare forest birds were not positioned using GPS devices which were not accessible to most of the people in Bulgaria at that time. The sites were mapped on topographic and other maps. Pygmy Owl was not proved as a breeder in the national park.

In Bulgaria, similar studies on the distribution, numbers, population densities and habitat preferences of mountain forest owls and woodpeckers were made during the last decades. During these studies Pygmy Owl and Tengmalm's Owl were found as widely distributed and locally common species in Western Rhodopes Mts and Northern parts of Rila Mt. (Nikolov et al. 2010, Shurulinkov et al. 2012). Tengmalm's Owl was found at many sites also in Mt. Vitosha (Nikolov et al. 2001). Woodpeckers were mapped systematically and their population densities were calculated in Strandzha Mt. and Belasitsa Mt. (Nikolov et al. 2011, Gerdzhikov et al. 2018). Large scale mapping of the sites of Three-toed Woodpecker and Capercaillie were made in many parts of the Bulgarian mountains in frames of projects for creation of action plans for the protection of these species in the country (Plachiyski et al. 2015, Plachiyski et al. 2018). Common breeding birds of Macedonian Pine (P. peuce) forests of Pirin Mt. and their population densities were studied by Nikolov (2005). In the other countries from the Balkan and Southern Carpathian region there are also some systematic studies on mountain forest owls, woodpeckers and other birds. The population of Tengmalm's Owl was studied in Mt. Kopaonik, Central Serbia, and a density of 7.7 territories/1000 ha was reported. The species was found mostly in Norway Spruce forests (Rajkovic et al. 2013). The distribution, biology and habitat requirements of the Pygmy Owl were studied in parts of Romanian Carpathians, where the population density was calculated at $6.1-7.3$ pairs/1000 ha (Mestecaneanu \& Mestecaneanu 2019). In this study Pygmy Owls were registered mostly in Norway Spruce forests. Mapping of the presence of Pygmy Owl was made also in the Greek part of Mt. Rhodopes (Gasteratos et al. 2015).

Despite the fact that the protected areas act didn't allow any large-scale construction in national parks, one of the three main ski zones - ski zone Bansko, expanded substantially in the period 2003-2006. Many new ski runs, lifts, roads and other facilities were created. A high number of new hotels and apartment houses were built in the foothills of the mountain. The ski tourism developed at high scale and caused serious threats to the biodiversity in Banderitsa River valley - such as degradation and fragmentation of forest habitats, logging, degradation of meadow habitats, disturbance. The results of these influences on the avifauna were not sufficiently evaluated especially on rare forest species throughout the whole national park. A local study of the effects of natural fragmentation in upland forests focused on edge and generalist bird species showed higher species richness and density in forest edges compared to forest interior (Nikolov 2013). In that study, rare and endangered owls and woodpeckers were not evaluated as well as the impacts of the man-made forest fragmentation caused by development of ski facilities. The edge effect 
found, in fact, confirmed previous findings from the temperate zone of Europe (Sisk \& Batin 2002).

In many studies across Europe the impacts of ski-tourism development, human disturbance and intensive forestry practices on these rare bird species were investigated. Negative effects of building ski resorts and winter recreation on birds are quite diverse and complex and new ski-resorts should be kept outside valuable nature areas (Korňan 2016). Ski-resort development and reducing the cover of old forests have negative effect on Tengmalm's Owl survival (Hakkarainen et al. 2007). The same authors stated that protection of about $15-20 \%$ of old forest containing over $150 \mathrm{~m}^{3} /$ ha of timber is likely to maintain the survival of Tengmalm's Owls at an adequate level. It was shown that cutting down the large diameter trees and removal of dead wood negatively affects the Tengmalm's Owl habitat in Spain (Dalmau et al. 1998). The importance of old-growth montane/boreal forests for the protection of Pygmy Owl was also underlined especially in the connection with the climate changes (Barbaro et al. 2016). Different types of silviculture practices were reviewed and compared according to their effect on forest bird assemblages (Korňan 2006).

Thiel et al. (2008) showed that Capercaillie in Central Europe avoids areas highly disturbed by recreation. Summers et al. (2007) showed that Capercaillie avoids woodland near gravel roads, presumably due to associated disturbance by vehicles, walkers and cyclists. On the other hand, movement to less disturbed habitat may result in increased density there, so impacting vital rates (Gill et al. 2001). In summer, mountain bike trails and hiker's restaurants were avoided by Capercaillies up to an average distance of $145 \mathrm{~m}$ and around winter infrastructure - up to $320 \mathrm{~m}$ (Coppes et al. 2017). The latter authors recommend a general reduction in recreation infrastructure density in key habitats, the establishment of undisturbed wildlife refuges with a diameter of at least $800 \mathrm{~m}$, as well as enhancing visual protection by maintaining a strip of dense understory along trails. Human disturbance reduces the Capercaillie's living space, possibly affecting hens more than cocks (Moss et al. 2014). Cases of Capercaillies killed on the cables of ski-lifts or by collision with fences were reported from Scotland and Central Slovakia (Watson \& Moss 2008, Saniga 2011). Similar case of a male Capercaillie killed on the cables of a ski lift was recorded in Pirin NP in 2002 (author's data). It was found that total density, species richness and diversity of forest bird assemblages of the original habitats before construction may be negatively affected by habitat alterations as a result of a ski resort building in the High Tatras (Korňan 2020).

During the recent years, a new management plan of the Pirin NP have been under preparation after passing the 10 years period validity of the plan from 2003. Ornithological data in the new plan were scarce and based mainly on old references, not on real field observations. The new plan proposed completely different philosophy and territorial scope of functional zones with advantages for the economic development instead of nature protection. The zone for touristic and sports facilities was significantly enlarged. A new zone for sustainable use of the forest resources was created where commercial logging would be allowed. Thus, the environmentally unacceptable plan was given to the court by the environmental NGOs and its implementation was temporarily suspended. Meantime WWFBulgaria (Danube-Carpathian Program) funded research on the key animals and habitats in the Pirin NP. Parts of the results of these studies are subject of the present work.

The main purpose of the present research was to conduct surveys in the same areas of the Pirin NP as it was done in 2001-2002 for the preparation of the national park management plan (Shurulinkov et al. 2003, Shurulinkov \& Stoyanov 2003) and to compare the distribution and population numbers of some target forest bird species of conservation importance. Moreover, we included some additional forest areas within the national park which are under threat following the spatial planning by the new proposed management plan of the protected territory (it can be seen at: http://www. 
pu-pirin.pirin.bg/documents/raboten-protzesrezultati/116-proekt-plan-za-upravlenie-nppirin-2014-2023-g). Initially we surveyed larger area which allowed us to collect more precise data on the distribution and population size of the target bird species. This could be helpful for decision making in the future process of spatial planning in the protected territory especially in the areas threatened by touristic development or forest management. Other main objectives of this study were to obtain more precise data on the habitat requirements of the target species and present data on their population densities.

\section{Material and methods}

\section{Study area}

Study area included the territory of the Pirin NP, situated in the northern part of Pirin Mt. This part of the mountain is largest and the highest, reaching $2914 \mathrm{~m}$ a.s.l. The national park was designated under the Bulgarian Protected Areas Act and now has a total area of 40,332 ha. The national park lies in the altitudinal range 950-2914 $\mathrm{m}$ a.s.1. (National Park Pirin Management Plan 2004-2013). It has key importance for the protection of alpine, subalpine and boreal forest ecosystems in the Balkan Peninsula, and thus was designated as an UNESCO World Natural Heritage site. Priority areas inside the park were those planned for development of new tourist (sport) zones or areas included in a new proposed zone for sustainable use of forest resources. The two existing strict nature reserves inside the national park were not included in the studies conducted in 2019. Only small areas of the Bayuvi dupki - Dzhindziritsa Nature Reserve close to its border were included because they were explored also in 2001-2002 and we needed data for comparisons.

Study area was placed in the forest zone and partially in Dwarf Pine (Pinus mugo) habitats which normally occur above the tree line at approximately 2000-2100 m a.s.1. Studies in Dwarf Pine habitat were due to the presence of Capercaillies during the breeding period (April-
May), especially in areas where some old trees grow (mostly Macedonian Pines $P$. peuce).

The Pirin NP has well represented forest zone consisting mainly of coniferous stands. The largest territories of the coniferous belt are covered by Macedonian Pine (P. peuce) and Bosnian Pine (P. heldreichii). These two species cover 7207 ha. Significant areas are covered also by Norway Spruce (Picea abies) (1636 ha), and Scots Pine (Pinus sylvestris) (4524 ha) habitat types and mixtures between them. Much smaller is the coverage of Silver Fir (Abies alba) (714 ha) and Austrian Pine (Pinus nigra) (810 ha) forests. Mixed forests of Beech/Silver Fir, Beech/Scots Pine and Beech/Norway Spruce types also have similar coverage -839 ha. Pure broad-leaved forests, mainly consisting of Beech (Fagus sylvatica), cover comparatively small territories (a total of 1166 ha). They have higher percent coverage in northern and northeastern lower parts of the Pirin NP, and locally on the western and southern slopes. Mean age of the forests in the Pirin NP is approximately 100 years. Old and well preserved Dwarf Pine (P. mugo) habitat is widely distributed above the forest zone (6231 ha) (Natura 2000 SPA Pirin - Standard Form, National Park Pirin Management Plan 2004-2013).

The research completed in 2001-2002 covered mostly the forests of Pirin Mt. above Predela, Bansko, Razlog, Dobrinishte and around the huts Pirin and Begovitsa. In 2019, many more new forest areas of the mountain were included.

\section{Bird survey}

This study is focused on forest bird species, most of them of high conservation status living in the Pirin NP - Pygmy Owl (G. passerinum), Tengmalm's Owl (A. funereus), Three-toed Woodpecker (P. tridactylus) and Capercaillie (T. urogallus). These species are quite sensitive to habitat changes and vulnerable to future human pressure.

A total of 100 survey days were spent by eight census takers in the periods April-May 2019 and September-November 2019. In 
2001-2002, six observers spent 48 survey days in the same periods of the year.

Specific methods were applied for each studied species. For the owls, we used night line transects with acoustic species calls (henceforth playback) at each 500 (700) m. In 2001-2002, we conducted 15 night counts (18:00-7:00 hrs) on $2-5 \mathrm{~km}$ transects with 38 playback points during spring (April-May) and autumn (September-November) periods. A total of 35 night transects ( $2-5 \mathrm{~km}$ long) with 80 playback points were checked in the same periods of the year in 2019. The owls were heard or seen not only at the study points but also along the transects between them. Each transect in particular year was visited once. All transects made in 2001-2002 were repeated again in 2019. Playback recordings were territorial calls and alarm calls of the particular species produced by mp3 players or smartphones. Playback was switched on for at least 5 minutes in selected habitat of the target species. For the Tengmalm's Owl imitation series were longer, lasting $10 \mathrm{~min}$.

In 2001-2002 a total of 20 daytime transects (7:00-18:00 hrs) for woodpeckers and Pygmy Owl were mapped. The length of the transects was between 2 and $5 \mathrm{~km}$. They were conducted in the periods April-May and September-November. A total of 41 daytime transects were made in 2019 in the same areas and periods of the year as in 2001-2002 and in some new, unexplored forested areas. For these species, we surveyed mostly ridges with suitable conditions for playback for both sides of the slopes covered by old forests. Playback imitations were used at some points for attracting Pygmy Owls during the day when the transects passed appropriate habitats. Although, the surveys were not capable to detect all existing territories, the daytime surveys for Pygmy Owl seemed sufficient for covering of much broader landscape areas than standard search in evening and morning hours (Shurulinkov et al. 2012). In Capercaillie counts, we searched for tracks in the snow, excrements or feathers. These studies were conducted only in spring, April-May, 2001, 2002, 2013-2014 and 2019. The leks were identified by observations or registering the tracks of lekking Capercaillies (specific trees with a lot of excrements under big branches and parallel lines of the wing-prints from the dragging wings nearby).

Annual monitoring on the numbers of Capercaillies during the last 20 years was also organized by the Pirin NP Administration. The data for the estimation of densities/numbers was provided by the rangers based on so called yearly estimates of population size and visits in all already known leks in spring period. That information was kindly shared with us. The methods used in these censuses are not reliable for absolute estimates, but we assume that general trends are correctly assessed.

\section{Data analysis}

Population densities of the target species were calculated on the basis of line transect counts with a distance of $250 \mathrm{~m}$ from both sides of the line. That distance allows the observer to hear the calls of the target species of owls and Three-toed Woodpecker even in unfavorable weather conditions.

GIS maps for the target species (A. funereus, G. passerinum, P. tridactylus and T. urogallus) were produced on the basis of their specific habitat requirements. These habitat requirements were taken from our previous studies and from existing publications from the Balkan region. Term "suitable habitat" in the map legends was characterized by forest type, age and altitude (within the borders of the national park, about $1000 \mathrm{~m}$ a.s.1.) as follows:

A. funereus and G. passerinum: all the coniferous forests above 70 years old, except $P$. nigra and P. mugo stands. All mixed forests (BeechFir, Beech-Scots Pine, Beech-Macedonian pine, Beech-Norway Spruce) above 70 years old, excluding the mixed forest with occurrence of oak, in 1000-2000 m a.s.l.

P. tridactylus: all coniferous forests above 80 years old, except $P$. sylvestris, $P$. nigra and P. mugo forests, in 1000-2000 m a.s.1.

T. urogallus: all forests above 70 years old, except oak stands, in 1000-2100 m a.s.1.

For every observation or survey point we described the main characteristics of the forest 
habitat including: dominant tree species (\%), additional tree species (\%), age, tree height, crown closure (0.1-1.0), presence of dead wood, percent of standing dead wood, existence of current or old logging. We also gathered data about the weather conditions for each transect or study point. That information was taken by every observer on field.

All data on forest habitats, transects, survey points and bird observations were used for GIS analyses. A layer of the preferred habitats inside the Pirin NP was created for every species. It is based on previous data about the habitat requirements of the target species in Pirin Mt. and other Bulgarian mountains (Shurulinkov et al. 2003, Shurulinkov et al. 2012, Plachiyski et al. 2018). The following layers were used during creation of GIS models of distribution of the species:

- the Pirin NP forest inventory database (owned by the Directorate of Pirin NP), regarding every stand's forest type and origin, tree species, age, CD 92/43 EEC habitat code (if belonging to); slope, aspect, altitude, soil, base rock; national legislation protection level - national park or a nature reserve within it. From this layer, suitable habitats for each species have been selected.

- the Pirin NP functional zones layer - according to the Pirin NP Management Plans/ Plan Drafts.

- additional layers - DEM (50x50 m raster layer), settlements, paved roads. National level database was originally created for the purpose of the JICA (Japan International Cooperation Agency)/WABD (West Aegean sea river Basin Directorate, Ministry of Environment and Waters, Bulgaria) Integrated Water Management project. Formerly available for free download from WABD website (www.wabd.bg).

For comparison of some of the values we used Fisher's exact test, calculated using automatic calculator at www.socscistatistics.com.

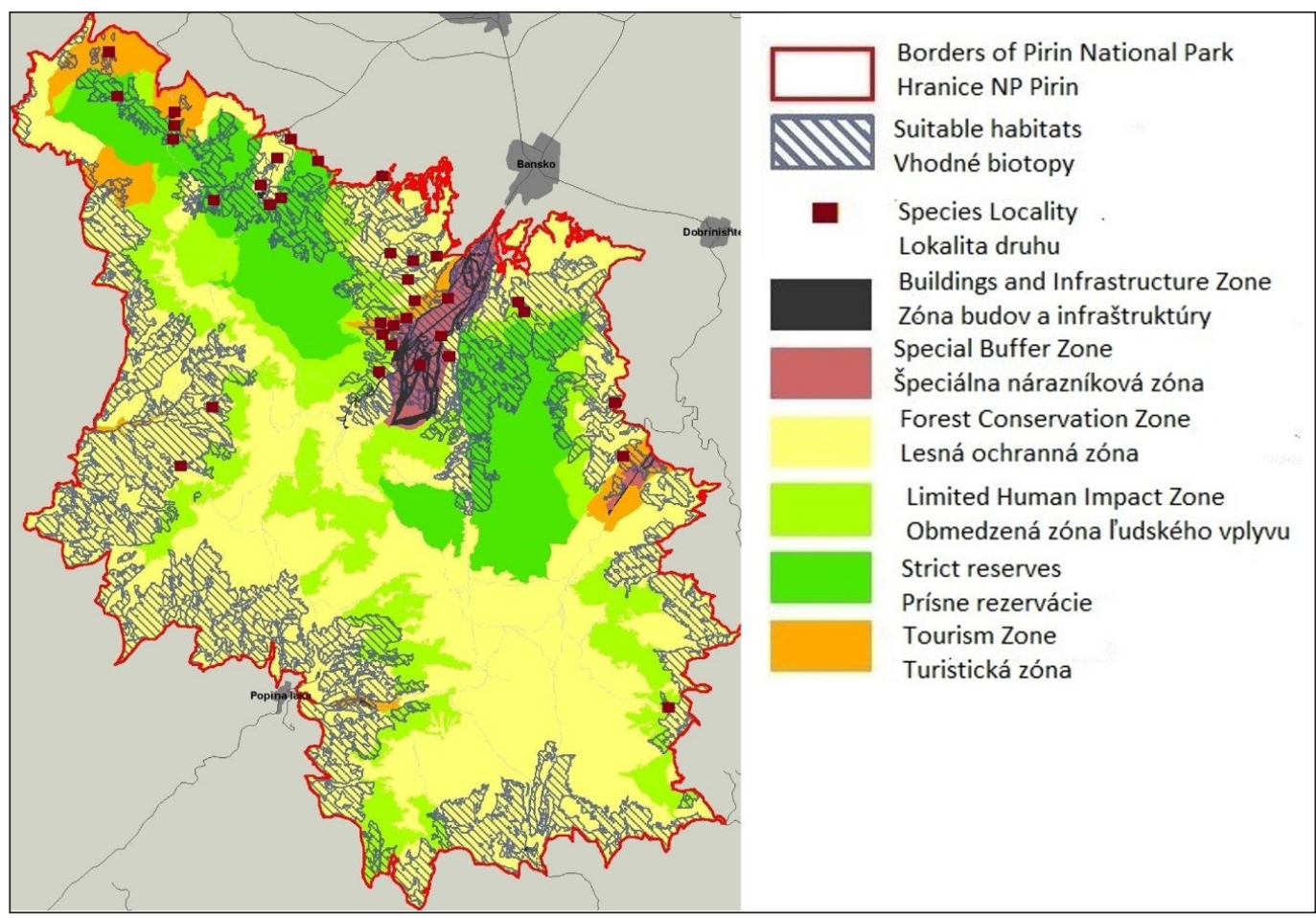

Fig. 1. Map of Tengmalm's Owl's suitable habitats and its sites found in 2019 (brown squares) and new proposed functional zones of the Pirin NP.

Obr. 1. Mapa vhodných habitatov pôtika kapcavého a zistené lokality výskytu v roku 2019 (hnedé štvorce) a nové navrhované funkčné zóny $v$ NP Pirin. 
Abbreviations used: a.s.l. = above sea level; Ind. = individuals; IUCN = International Union for Conservation of Nature; NP= National Park; Mt. = mountain; WWF $=$ World Wildlife Fund.

\section{Results}

\section{Tengmalm's $O w l$}

A total of 29 occupied territories (territorial males) were found (Fig. 1). In total, 35 birds were recorded (Fig. 1). Of them, 16 territories detected in 2001-2002 were confirmed again or were in a close vicinity. The other 13 territories were in newly studied parts of the Pirin NP (9) or in previously studied but far from the former sites (4). The surface of the suitable habitats of the species covered by the research made in 2019 was 3020 ha $-23 \%$ of all appropriate habitats in the Pirin NP (13 089 ha). Mean population density for suitable habitat was 9.6 territories/1000 ha. Taking in account the obtained results and the percent of occupied habitats covered during the present research we can estimate the actual numbers of the Tengmalm's Owl in the Pirin NP on 100-130 breeding pairs.

If we compare the abundance on the same points studied in both study periods $(\mathrm{n}=38)$, a a decrease of $30.4 \%$ in the species abundance was detected when we compared the abundance of 23 territorial males ( $60.5 \%$ positive records) found in 2001-2002 with 16 territorial males (42.1\%) detected in 2019. The decrease is not significant (Fisher's exact test $=0.1681, \mathrm{df}=1$, $\mathrm{P}>0.05)$.

Decrease in species abundance was much more obvious in the southern and southwestern parts of the national park, where all the previously known Tengmalm's Owl territories were abandoned. In 2001-2002, there were four existing territories of the species, while in 2019 we found none. In the area of ski zone Bansko and Banderitsa River valley, the number of the territories remained stable, but their spatial distribution changed substantially. Most of the Tengmalm's Owls were found in the periphery of the ski-zone, far from Banderitsa Glade, being at much lower or higher altitude. The aver- age distance of the occupied sites to Banderitsa Glade (the center of the ski resort facilities nowadays) was $520 \mathrm{~m}$ in 2001-2002 ( $\mathrm{n}=9)$ and $949 \mathrm{~m}$ in $2019(\mathrm{n}=9)$. New territories were found again mostly in northern and northeastern parts of the Pirin NP. From the western slopes two new territories were found.

The species was found predominantly in pure coniferous forests - mostly Norway Spruce (P. abies), Macedonian Pine (P. peuce) and Silver Fir (A. alba) forests (Fig. 2). All recorded sites except one were inside our GIS based model of suitable habitats for the species. In some cases, Scots Pine (P. sylvestris) stands were also occupied. The species was often present in mixed coniferous forests composed of 2-3 tree species. One territory was found in pure Austrian Pine (P. nigra) forests at 1232 $\mathrm{m}$ a.s.l. Occurrence of the Tengmalm's Owl in this habitat type is extremely rare in Bulgaria. In some cases, low dominance values (below $10 \%)$ of other tree species such as Beech $(F$. sylvatica), Dwarf Pine (P. mugo) and Rowan (Sorbus aucuparia) were recorded in the stands with the presence of the Tengmalm's Owl. In 24 sites $(82.8 \%)$, there were high density of dead standing or fallen wooden trunks. Canopy closure varied between 0.5 and 0.9 , with average value of 0.7.2 $(\mathrm{n}=14)$. Site altitude varied between 1085 and $2020 \mathrm{~m}$ a.s.l., on average 1648 m a.s.l. $(n=29)$.

\section{Pygmy Owl}

Pygmy Owl was not proved as a breeder in the national park during the first phase of the study in 2001-2002. In 2019, a total of 20 occupied territories (territorial males) were recorded (Fig. 3). Two of the sites were found in spring period and 18 during autumn. Spring sites were recorded in the vicinity of running Dobrinishte ski resort and in the upper basin of Oshtavska River. The surface of the appropriate habitats of the species covered by the research made in 2019 was 3020 ha $-23 \%$ of all appropriate habitats in "Pirin" NP (13 089 ha). Mean population density in suitable habitats is 6.6 territories/1000 ha. Taking into account the obtained results and the percentage of occupied 


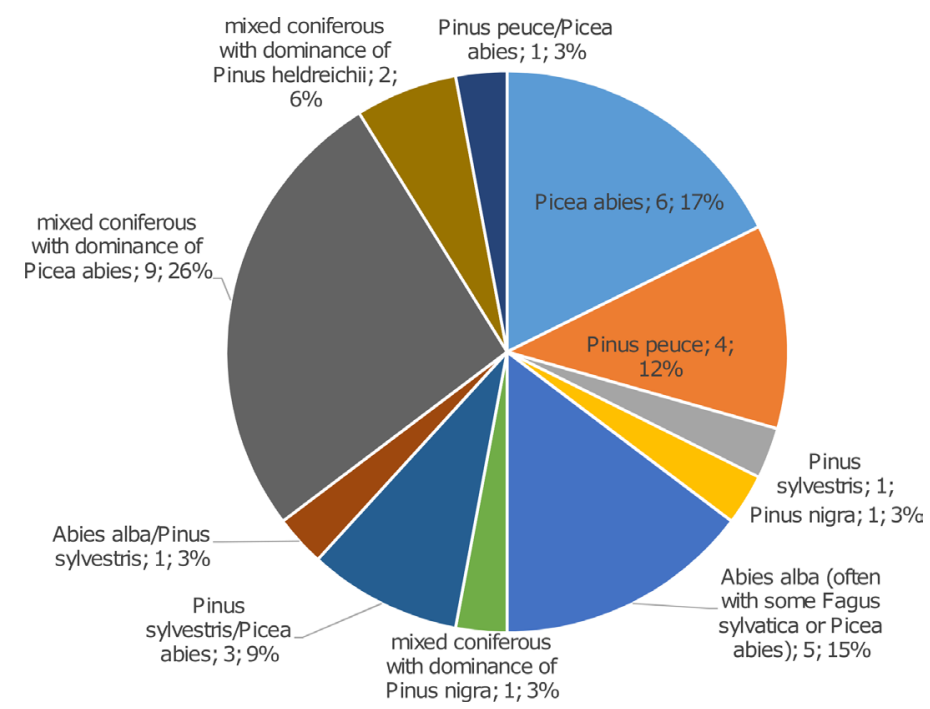

Fig. 2. Habitat associations of all recorded Tengmalm's Owls in the Pirin NP in 2019. The number of sites of the species and their percentage from all sites found are given for every habitat (see also Fig. 4, 7).

Obr. 2. Biotopové väzby všetkých zistených jedincov pôtika kapcavého v NP Pirin v roku 2019. Pre každý biotop je vyznačený počet lokalít druhu a ich percentol zo všetkých lokalít (vid' aj obr. 4, 7).

habitats covered during the present research, we can estimate the actual numbers of the Pygmy Owls in the Pirin NP on 70-100 breeding pairs.

Most of the sites of Pygmy Owl are in stands dominated by Norway Spruce (Fig. 4). Other main type of habitat occupied by the species are Macedonian and Scots Pine forests (often with admixture of Norway Spruce. Only two sites were found in pure stands of Macedonian Pine and Bosnian Pine. In two cases Pygmy Owl, was found in spruce-beech-fir mixed forest. In all cases, the forest stands had natural tree and age structure. All recorded sites are inside our GIS based model of suitable habitats for the species (Fig. 4). At two sites there were signs of old forest cuttings of not more than $10 \%$ of trees. Canopy closure varied between 0.5 and 0.9 . Site altitude varied between $1612 \mathrm{~m}$ a.s.l. and $1870 \mathrm{~m}$ a.s.l., averaging $1753 \mathrm{~m}$ a.s.1.

\section{Tree-toed Woodpecker}

This very rare and critically endangered species in Bulgaria was found only in two sites during spring 2019 and at 13 sites during the period 2001-2016. All were situated in suitable habitats predicted by the initial GIS model for this species (Fig. 5). The first site from 2019 was in a forest territory proposed for development of the ski-zone Dobrinishte - a male was observed on 4 May. It was observed in old (90-100 years) Macedonian Pine and Norway Spruce forest, at $1800 \mathrm{~m}$ a.s.l. The second observation from 2019 was in the vicinity of the Makliishta peak. Single individual was heard and seen on 2 May in Norway Spruce forest with low admixture of Silver Fir at $1601 \mathrm{~m}$ a.s.l.

According to the GIS model the total area of appropriate habitats of the species is 7,370 ha. About $20 \%$ of them (1487 ha) were covered by the research made in 2019 . The total population density was 1.35 pairs/1000 ha.

\section{Capercaillie}

A total of 23 point occurrences were found, and grouped in 16 lek sites. About $24 \%$ of the appropriate habitats of the species in the Pirin NP were covered by the research made in 2019 (3664 ha from a total of 11,722 ha). Average density of the males in the studied territory is 10.9-15.0 ind./1000 ha, but they are concentrated at the leks during the breeding period. The sex ratio (males/females) is about 1:1.9 (data 


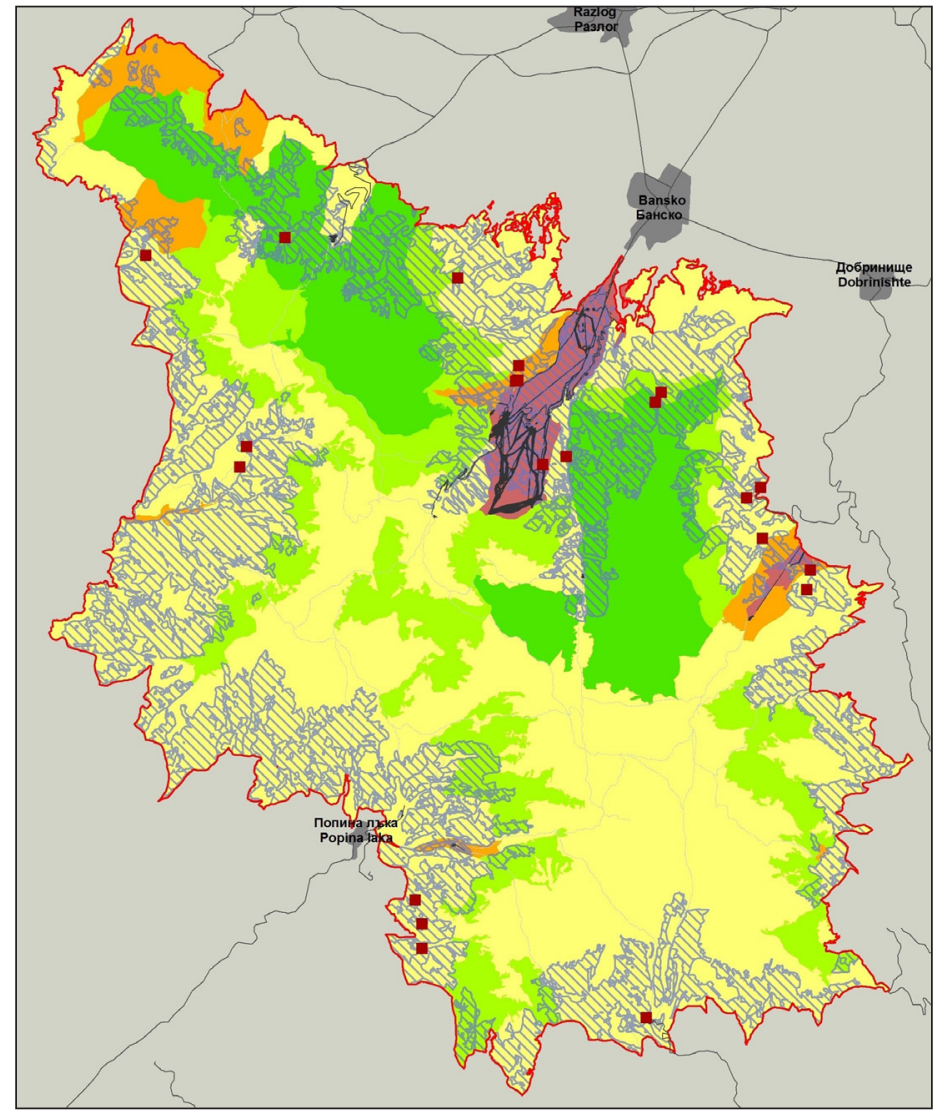

Fig. 3. Map of Pygmy Owl's suitable habitats and its site found in 2019 (brown squares) and new proposed functional zones of the Pirin NP. For map legend see Fig. 1.

Obr. 3. Mapa vhodných biotopov kuvička vrabčieho a zistených výskytových lokalít v roku 2019 (hnedé štvorce) a novo navrhnuté funkčné zóny v NP Pirin. Pre legendu vid' Obr. 1.

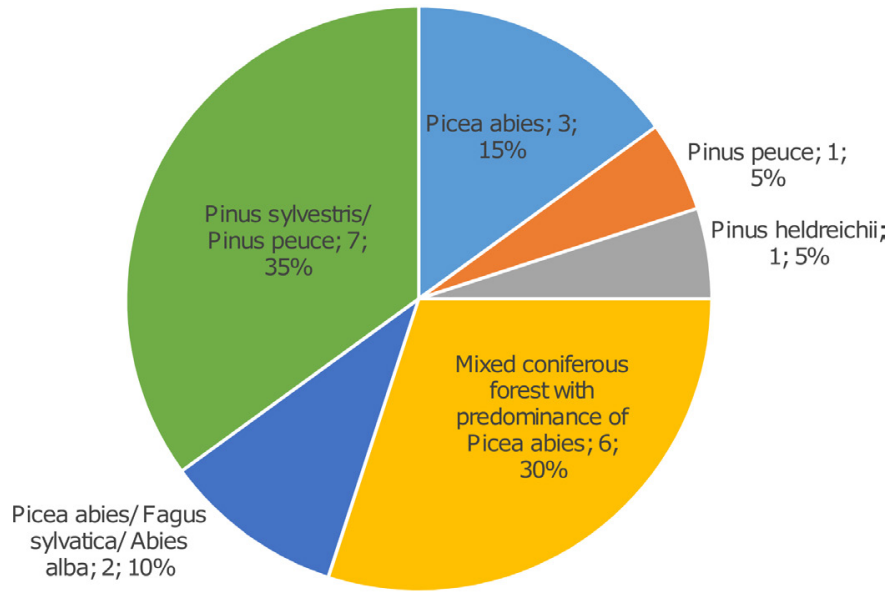

Fig. 4. Habitat associations of all recorded Pygmy Owl in the Pirin NP in 2019.

Obr. 4. Biotopové väzby všetkých zistených jedincov kuvička vrabčieho v NP Pirin, r. 2019. 


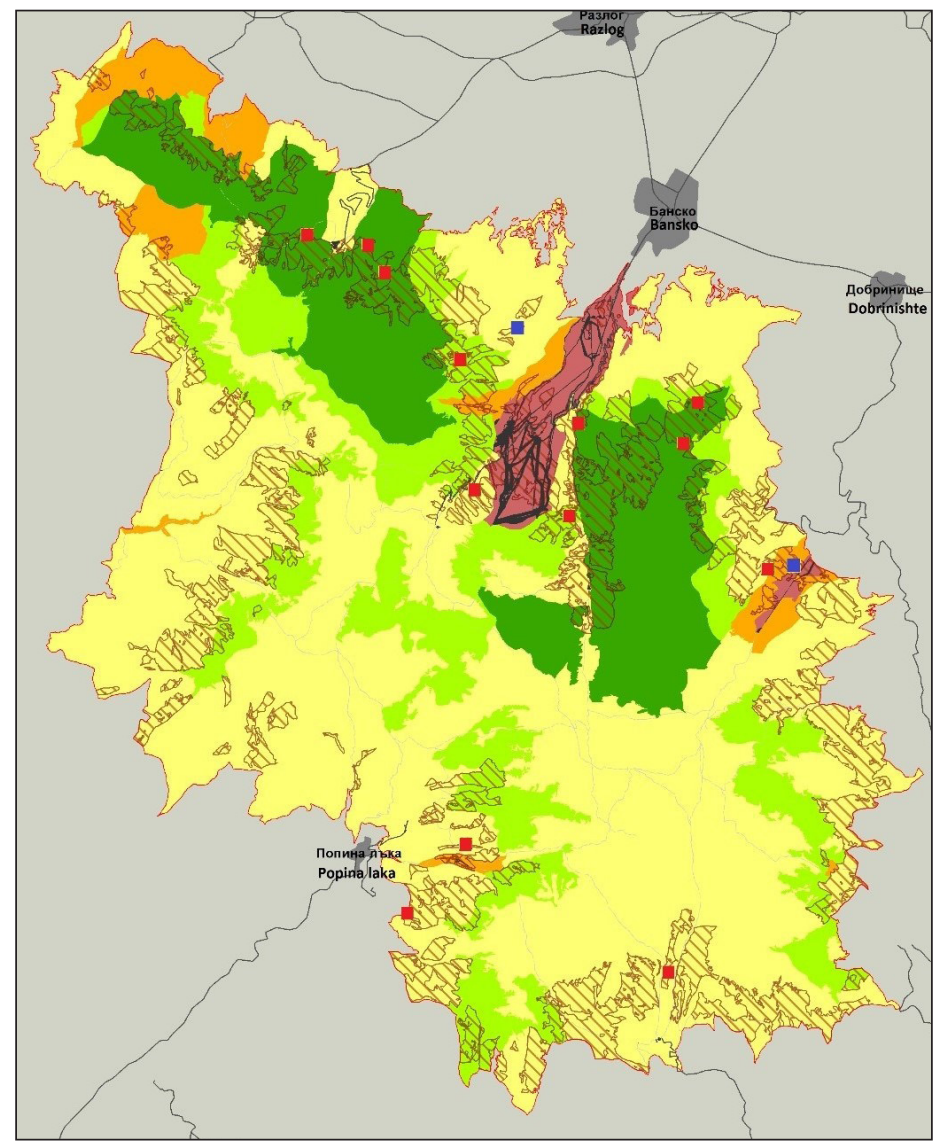

Fig. 5. Map of Three-toed Woodpecker suitable habitats and its sites found in 2001-2016 (red squares) and 2019 (blue squares) and new proposed functional zones of the Pirin NP. For map legend see Fig. 1.

Obr. 5. Mapa vhodných biotopov d'ubníka trojprstého a jeho lokalít z rokov 2001 - 2016 (červené štvorce) a 2019 (modré štvorce) a nové navrhované funkčné zóny v NP Pirin. Pre legendu vid' Obr. 1.

collected by the Administration of the Pirin NP), thus the total population density of the species can be estimated at 20.9-28.5 ind./1000 ha.

All observations were from April and May. Most of these sites were detected by tracks in the snow or by excrements. In almost all confirmed old sites (found in 2001-2002), the bird numbers substantially decreased. Furthermore, the species absented in some old lek sites - upper part of Bezbog ski run, and most former sites in ski zone Bansko. In 2001-2002, the number of the proved leks was again 16 within the national park territory, but we estimated presence of 70 Capercaillies (both sexes) in three of them. During the period 2013-2014, there were 17 leks and further eight sites of solitary birds. In that period, nine leks found in 2001-2002 were confirmed, two were abandoned and five were not investigated. Eight leks were newly found. The overall species distribution in the studied area comparing 2013-2014 and 2019 surveys is presented in Fig. 6.

The decrease of Capercaillie numbers was also confirmed by the estimates conducted by the national park rangers between 2009 and 2011 (decrease from 154 to 92 ind.). All data on population dynamics of the species in the period 2001-2019 is presented in Table 1.

Capercaillies were found in various forest habitats in the Pirin NP mainly in Macedonian Pine, Bosnian Pine, Scots Pine, Beech-Fir, Norway Spruce, and Norway Spruce-Scots Pine 


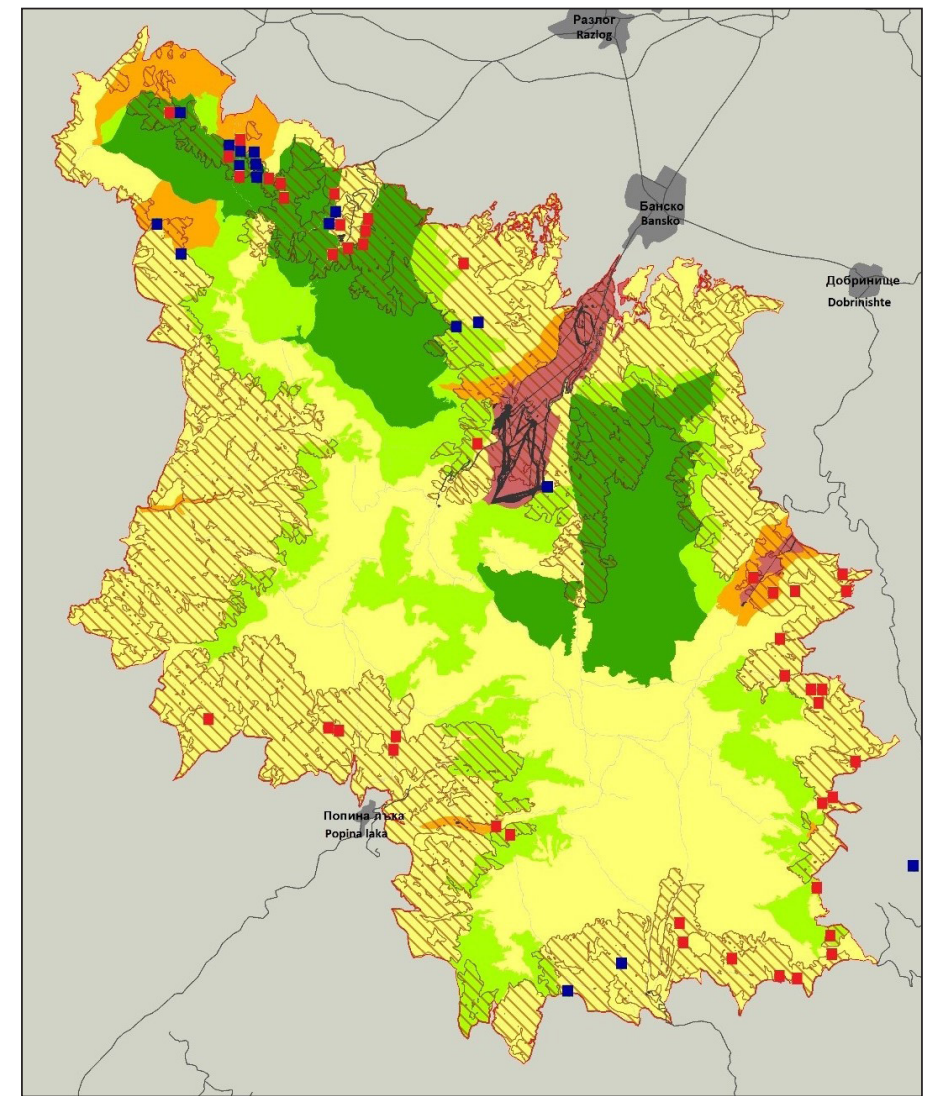

Fig. 6. Map of Capercaillie suitable habitats and its sites (leks) found in 2013-2014 (red squares, ex Valchev 2014) and 2019 (blue squares) and new proposed functional zones of the Pirin NP. For map legend see Fig. 1.

Obr. 6. Mapa vhodných biotopov hlucháňa hôrneho, jeho lokalít (tokanísk) v r. 2013 - 2014 (červené štvorce, ex Valchev 2014) a 2019 (modré) a nové navrhované funkčné zóny NP Pirin. Pre legendu vid' Obr. 1.

stands (Fig. 7). The highest number of sites was found in Macedonian, Scots and Bosnian Pine forests. The canopy closure was $0.5-0.6$. In most of the sites there were high numbers of dry standing and fallen trees. Many sites, especially leks, were around the upper tree line in sparsely growing Macedonian and Scots Pines within the Dwarf Pine habitat. The site altitude varied between 1475 (individual bird) and $2121 \mathrm{~m}$ a.s.l.

\section{Discussion}

Tengmalm's Owl

Population numbers, trends, changes in the distribution

The numbers of the Tengmalm's Owl population along transects of the same or equal length decreased by $30.4 \%$ between 2001 and 2019 . When considering nine new territories found in new surveyed areas of the mountains and possible long-distance movements of the same individuals between or within years (Badosa et al. 2007, S. Pačenovský, pers. comm.), we can suppose that overall trend in abundance of the Tengmalm's Owl is most probably slightly decreasing. Actual estimation of the whole 
population (100-130 pairs) is lower compared to the published data from 2003 (180-200 pairs) (Shurulinkov et al. 2003). However, wider area was covered by the current study.

The decrease in Tengmalm's Owl numbers can be due to a number of co-existing negative factors. Possibly climate change (global warming and habitat drying) has consequences on populations as it was proved that many mountain species showed shrinking of ranges (Freeman et al. 2018, Trautman 2018). The Tengmalm's Owl has disappeared from stands having southern, southwestern and southeastern exposures dominated by Macedonian Pine and Scots Pines. Climate seems to be the one of the factors affecting the Tengmalm's Owl distribution. It is an owl that has clear preferences for cooler and more humid climatic conditions (Castro et al. 2008). Thus, the climate change during the last 20 years has probably negatively influenced habitat occupancy patterns especially close to its southern distribution limit. Even in northern Europe, it is assumed that global warming has negative impact on Tengmalm's Owl. The increase of day temperatures effected the length of the snow cover period during winter and negatively affected the abundance of a main food sources - voles and lemmings (Mysterud 2016). These animals were reported to reproduce during winter (Stenseth \& Ims 1993). Their culmination patterns reported in the past are negatively changed during recent years because of ice cover formation as result of warmer winters and consequence of increasing of $\mathrm{CO}_{2}$ concentration under the snow. The accumulation of $\mathrm{CO}_{2}$ lead to avoidances of such affected areas by the voles.
In addition, the breeding numbers of Tengmalm's Owl can significantly fluctuate between years depending on food (mostly voles and insectivores) supply (Korpimäki 1994, Saurola \& Francis 2004). In Central Europe three year and five year population cycles were described for Apodemus flavicollis and Myodes glareolus respectively (Zarybnicka et al. 2017). In Finland, the breeding population size of the Tengmalm's Owl and the clutch size are positively correlated with Microtus voles' abundance (Korpimäki 1981). Moreover, we encountered and documented quite wide scale of sanitary cuttings in the southern parts of the Pirin NP. This type of forest management can have strong negative influence on the amount of dead wood in the stands, thus lead to decrease of the numbers of old forest species such as Black Woodpeckers (Czeszczewik et al. 2013), which are the most important cavity producers for the Tengmalm's Owl.

Average population density of the species in the Pirin NP was calculated at 9.6 territories/1000 ha of appropriate habitat which is comparatively high value. For comparison the same value at Kopaonik Mt., Central Serbia is 7.7 (Rajkovic et al. 2013), at Krim Mt., Central Slovenia 2.8 (Vrezec 2003), in France 6-13 (Jonieniaux \& Durand 1987), in W-Finland 0.1-2.6 (Korpimäki \& Norrdahl 1989), in Sweden up to 4.8 in peak years (Kallander 1964).

Up to now, the Tengmalm's Owl population in Banderitsa valley and around Bansko ski zone is still stable. It could be explained by the presence of optimal habitats in the vicinity dominated by Norway Spruce and Macedonian

Table 1. Population estimates of the Capercaillie in the Pirin NP in 2001-2019.

Tab. 1. Odhady početnosti hlucháňa hôrneho v Národnom parku Pirin v rokoch $2001-2019$.

\begin{tabular}{llll}
\hline Years / Roky & $\begin{array}{l}\text { Number of leks / } \\
\text { Počet tokanisk }\end{array}$ & $\begin{array}{l}\text { Number of indviduals / } \\
\text { Počet jedincov }\end{array}$ & Source / Zdroj \\
\hline $2001-2002$ & 16 & $150-200(60-70$ males) & Shurulinkov \& Stoyanov (2003); own \\
2009 & $?$ & $154(53$ males) & Pirin NP Directorat \\
2011 & $?$ & 92 & Pirin NP Directorat \\
$2012-2014^{*}$ & 25 & $46-84$ (males) & Plachiyski et al. (2018) \\
$2013-2014$ & 17 & 97 & Present study, Valchev (2014) \\
2019 & 16 & $40-55$ (males) & Present study \\
\hline
\end{tabular}

*for the whole Pirin Mt. 
Pine. Thus, any planned new area expansion of the ski zone will greatly affect the numbers of Tengmalm's Owl territories. At least seven Tengmalm's Owl sites are in a serious threat taking into account the existing development plans. It should be underlined that if the proposed expansion of the ski zone continues, the new neighboring areas would become suboptimal for Tengmalm's Owl, especially those in Damyanitsa River valley. In the northern part, many suitable territories are already occupied by other pairs of this species and the development of the ski zone may lead to stronger intraspecific competition which potentially can reduce the breeding success as it is reported for other bird species (Denac 2006). Expected reduction of the primeval forests as a consequence of ski-resort development can lead not only to the reduction of the appropriate nest trees but also to decrease of Tengmalm's Owl adult survival rates as in was shown in Finland (Hakkarainen et al. 2007).

\section{Habitat}

Tengmalm's Owl on Pirin Mt. shows clear preference to coniferous forest despite the existence of quite large areas covered by beech forests, especially in northern, northwestern and northeastern parts of the mountain. Species has been found much more often in broadleaf (beech) stands in the Slovak Carpathians (Šotnár et al. 2020) and in the Bulgarian part of Stara planina Mts (Nikolov et al. 2001, Nikolov 2002). Mixed forests (Norway Spruce/Beech/Silver Fir or Scots Pine/Beech) were also proved as good and even preferred habitats for the Tengmalm's Owl in in Jura Mt., in France and Switzerland (Cramp 1985) and in Rila Mt. (around Rila monastery), Plana Mt. and Osogovo Mt., in Bulgaria. In the Pirin NP, these mixed forest habitats are distributed quite locally and don't grow at large areas which can explain the small number of Tengmalm's Owl locations there.

\section{Pygmy Owl}

Population numbers, trends, changes in the distribution

Pygmy Owl was not found in the surveys conducted in 2001-2002 in the Pirin NP or further past. Different monitoring technique was applied in the first period not comparable with the one in 2019. The surveys were carried out for a very short time period during late evenings and early mornings. After improvement of the technique that included playbacks during the whole day along the forest transects, the species was found in many parts of the Pirin NP. First evidence of occurrence in the park was given

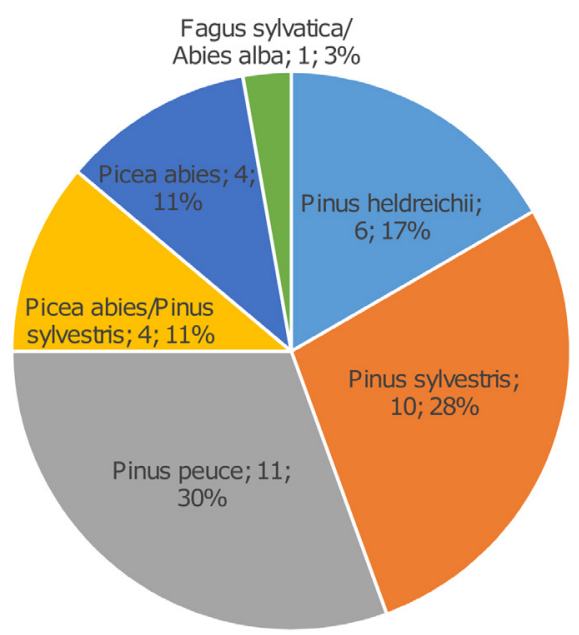

Fig. 7. Habitat associations of all recorded Capercaillie leks in the Pirin NP in 2001-2019.

Obr. 7. Biotopové väzby zistených tokanísk hluchán̆a hôrneho v NP Pirin, 2001 - 2019. 
by R. Kolchagov in autumn of 2003 when one calling male was heard at Banderitsa Glade. Afterwards, one male was heard in autumn of 2014 in an area under Begovitsa hut (Sylvia Dyulgerova pers. comm.). In the present study, the species was found in eight different parts of the Pirin NP and can be considered as widely occurring in its forest zone. Two old sites were not confirmed in 2019, but the species was present in neighboring areas (approximately 830 and $920 \mathrm{~m}$ further). The species might have increased in numbers in the park during the recent years which can be the result of low intensity of logging with a total ban of clear cuttings and other major cuttings and the decrease of Tengmalm's Owl which occurs in similar habitats and could be a competitor (Lenz 1967, Schönn 1980). Undoubtedly Pygmy Owl presence in the Pirin NP is not a result of a new colonization and it must have occurred there before. The species has relict distribution as in Rila Mt., Western Rhodopes Mts., southern part of Pirin Mt. and Central Stara Planina Mts. (Spiridonov et al. 2015a).

Mean population density of the species in the Pirin NP was estimated on 6.6 territories $/ 1000$ ha. For comparison, Northern Rila Mt. has value 6.0 (Pačenovský \& Shurulinkov 2008), the Western Rhodopes Mt. 2.18 (Shurulinkov et al. 2012), Slovak mountains 9.6-10.5 (Glutz von Blotzheim \& Bauer 1980), the Bayerisher Wald, south Germany - 1.2-4.2, depending on annual food abundance (Scherzinger 1974).

Six Pygmy Owl sites were found in the proposed enlargement areas of existing or newly planned ski zones. Three are in the proposed enlarged area of Dobrinishte ski zone, two in such area close to Bansko ski zone and one in a new proposed ski zone in the northwest of Pirin Peak. Other seven sites of Pygmy Owls are in the new planned zone for sustainable forestry management in the Pirin NP, which might negatively affect their populations living in intact areas without any forestry activities during last 30 years.

\section{Habitat}

The Pygmy Owl distribution in Pirin Mt. lies in a high forest belt from approximately $1612 \mathrm{~m}$ a.s.l. to $1870 \mathrm{~m}$ a.s.l. In the Romanian Carpathians, the sites of the species were found mostly in the belt $1500-1600 \mathrm{~m}$ a.s.1. at much lower altitudes and predominantly in old Norway Spruce forests (Mestecaneanu \& Mestecaneanu 2019). In Pirin Mt., having much more southern location than Carpathians and more diverse and mild climatic conditions, the forest belt and Pygmy Owl reaches much higher altitudes. Furthermore, the species lives in much diverse forest habitats including not only Norway Spruce but a number of Pine (Pinus) species. Pygmy Owl is also predominantly confined to spruce forests in Western Rhodopes Mts. including their Greek part (Shurulinkov et al. 2012, Gasteratos et al. 2015).

Bosnian Pine forests have to be mentioned as a rare habitat for the Pygmy Owl. Pygmy Owl has been recorded in pure Bosnian Pine forest only in Slavyanka Mt. Despite the presence of some old stands of Austrian Pine (P. nigra) in Pirin Mt., the species was not found there. A case of finding this species in such habitat type is reported from Montenegro (Rašajski \& Gavrilov 1983). In French Prealps, Pygmy Owl prefers mostly Fir-Beech and Norway SpruceSilver Fir forests and avoids pure Norway Spruce and pure Beech forests (Barbaro et al. 2016).

\section{Three-toed Woodpecker}

\section{Population numbers, trends,} changes in the distribution

Three-toed Woodpecker was relatively common in the area of Pirin Mt. in the past (before 1975) including in the territory of the national park nowadays (Simeonov 1975). According to the standard form of the Pirin Natura 2000 Special Protected Area (SPA) the population of Three-toed Woodpecker was estimated on 20 pairs in 2010 . 
There were 13 observations of the species for the period 2001-2016. Three of them were in the Bayuvi Dupki - Dzhindzhiritsa Nature Reserve. Single observations are also from Begovitsa Hut and Pirin Hut, both in 2014. Taking in account the total surface of the appropriate habitats of the species - 7370 ha, and the obtained population density of 1.35 pairs/1000 ha, the number of Three-toed Woodpecker pairs can be estimated on 10. Population densities in other locations in Bulgaria and Europe are in most cases higher compared to these in the Pirin NP: e.g. in the Western Rhodopes Mts. 1.5 pairs/1000 ha (Shurulinkov et al. 2012), Austria 4 (Cramp 1985), Finland 0.2-6.9 (Pakkala et al. 2002).

We can conclude that the species has a very low (10-15 breeding pairs) and probably isolated population in the Pirin NP. The population trend for the period 2001-2019 is unclear because of the very small number of observations not allowing any conclusions. Long term population trend (1970-2019) shows marked decrease.

The presence of Three-toed Woodpecker in the area above Dobrinishte was proved since 1995 when a nest was found in the territory of the national park (Nankinov 2002). The observations from 2016 and 2019 are about 1.0-1.5 $\mathrm{km}$ away, at higher altitude.

Based on old published data (Simeonov 1975), the long-term decrease in numbers of the Three-toed Woodpecker can be confirmed. The most probable explanation is in naturally low numbers and high isolation of this subpopulation that may lead to higher risk of inbreeding and lowering population fitness. Even if we accept that the connectivity across the range of all Rilo-Rhodopean populations (in Bulgaria and Greece) is preserved, negative effects of isolation cannot be excluded due to low population level, not exceeding 230 pairs (Spiridonov et al. 2015b). Unfortunately, that population is completely isolated from the closest population living in the Western Balkans (SW Serbia, W North Macedonia, Montenegro, Bosnia and Herzegovina and possibly Albania) because there are no appropriate habitats that can be used as "stepping stones" between them. Other existing threat for the Three-toed Woodpecker is the permanent sanitary logging of old growth coniferous forests which is proved to be one of the most important negative factors for the species survival (Wesolowski et al. 2005). Other clear cuttings, including for new ski runs, also threaten the species habitats leading in some cases (Bansko ski zone) to their fragmentation and lowering their quality (age structure, decreased crown closure, lower amount of dead wood, etc.). Forest fragmentation as a result of commercial logging or construction of ski resorts has strong negative impact on Three-toed Woodpecker populations (Amcoff \& Eriksson 2001, Imbeau \& Desrochers 2002). It should be emphasized that losing even few pairs of a highly threatened species can have impact on its future survival in the Pirin NP.

\section{Habitat}

All locations of the species in Pirin Mt. are situated in the coniferous belt of the mountain, mostly in Norway Spruce and Macedonian Pine forests and in mixed forests of these two tree species. In the other mountains from the species Balkan range, it also lives mostly in pure coniferous stands with dominance of Norway Spruce (Nikolov et al. 2010, Shurulinkov et al. 2012) or Scots Pine (Gorman 2004). In Poland, the species also nests in Oak-Hornbeam forests, although in much lower numbers compared to pure coniferous forests (Wesolowski et al. 2005). In northern taiga it also lives in other forests as Larix sp., Betula sp., Salix sp. and others (Cramp 1985).

In the Pirin NP, all territories of the Threetoed Woodpecker were found in the altitudinal belt 1400-2100 $\mathrm{m}$ a.s.1. In Carpathians, the species lives in old Norway Spruce and mixed forests situated in much lower altitudes, 400-1800 m a.s.l. (Danko et al. 2002, Butiev et al. 2005). 


\section{Capercaillie}

Population numbers, trends, changes in the distribution

We found a total of 16 leks of the species with 40-55 males. The numbers are slightly lower to these presented by Plachiyski et al. (2018) - 25 leks with 46-84 males for the period 2008-2015. At least 5 years have passed between these two censuses, so the differences could mark a negative trend in numbers which can also be supported from the other available sources for the period after 2001-2002.

The total population density of the species in the Pirin NP can be estimated at 20.9-28.5 ind./1000 ha. In Russia and Scotland, density value varies between 20 and 60 ind./1000 ha (Watson \& Moss 2008) so that the densities in the Pirin NP are close to the lowest estimates for these countries.

The explanations for the population abundance decrease of Capercaillie cannot be related only to the enlargements of the ski zones (ski zone Bansko) in the national park. The decrease was recorded even in areas without visible human influence. Other possible reasons for the observed trend are forest fires, avalanches, windstorms leading to large damages in the forest, disturbance by tourists and forest workers and poaching. Some of these potentially negative factors were pointed in Bulgaria by Plachiyski et al. (2015). Undoubtedly, the negative effects of the new ski facilities, mostly in ski zone Bansko, are visible in local extinctions. Threats such as disturbance by people, the existence of new sport infrastructure, roads and buildings of different types, noise, degradation and fragmentation of the forest habitats were also underlined by Valchev (2014). During the last decade, the skiing season started later in winter and lasted longer than before, until April, and approximately matches the season of active mating of the Capercaillies. Negative impacts of ski tourism on the Capercaillie populations are recorded also in other European countries (Thiel et al. 2008, Moss et al. 2014, Rosner et al. 2014).
Habitat

Capercaillie leks in the Pirin NP are situated mostly in mature Pinus (P. peuce, P. heldreichii and $P$. sylvestris) forests close to the upper tree limit approximately at 2000-2100 m a.s.1. Parts of them are even in sparsely forested areas covered by Dwarf Pine (Pinus mugo). Only in one case during the present study the species was registered in mixed forest. Other subpopulations of the Capercaillie in Europe (Russia, Spain) are often detected in mixed or pure broad-leaved stands (Cramp \& Simmons 1980). In Bulgaria and Balkans, breeding of the Capercaillie in broad-leaved forests (mainly Beech) is very rare and was reported in the past from Stara planina Mts. (Boev et al. 2007) and more recently from Western Rhodopes Mts. (Plachiyski et al. 2015).

\section{Acknowledgements}

This research was funded by the project "Pirin campaign support FY19" of WWF - Bulgaria. We thank to our colleagues Georgi P. Stoyanov, Teodor Trifonov, Yana Yordanova and Michaela Ilieva, who participated in the field work in 2001-2002 or 2019. We thank also to Katherina Rakovska (WWF- Bulgaria) for her help in the organization and planning of the study and to Samuel Pačenovský and two anonymous referees for their valuable comments on the manuscript. We are grateful to the Administration of the Pirin NP for providing their data on Capercaillie numbers.

\section{Súhrn}

Aktuálny stav, rozšírenie, početnost' a stav ohrozenia boli študované na území Národného parku Pirin v Bulharsku u 4 lesných druhov vtákov pôtika kapcavého (Aegolius funereus), kuvička vrabčieho (Glaucidium passerinum), d'ubníka trojprstého (Picoides tridactylus) a hlucháňa hôrneho (Tetrao urogallus). Analýzy na základe vrstiev GIS boli robené pre zistenie rozloženia vhodných biotopov pre všetky študované druhy v Národnom parku. Početnost' a rozšírenie týchto druhov bola porovnaná s predchádzajúcimi štúdiami robenými v priebehu posledných 20 rokov a niektorými publikovanými zdrojmi pred rokom 2000. Aktuálne tam bolo zistených 29 teritórií pôtika kapcavého, 20 teritórií kuvička 
vrabčieho (nový druh zistený v národnom parku), 16 tokanísk hlucháňa hôrneho a 2 teritóriá d’ubníka trojprstého.

\section{References}

Amcoff M. \& ERIKsson P. 2001: Metodik för inventering av tretåig hackspett (Methods to monitor threetoed woodpecker). - Demonstration of methods to monitor sustainable forestry EU/LIFE project 10. (in Swedish with English summary).

Badosa E., Bonada A., Lopez A., Potrony D. \& Salo R. 2007: First long-distance movement of a Tengmalm's Owl Aegolius funereus recorded in the Pyrenees, Spain. - Revista Catalana d Órnitologia (23): 44-47.

Barbaro L., Blache S., Trochard G., Arlaud C., De Lacoste N. \& Kayser Y. 2016: Hierarchical habitat selection by Eurasian Pygmy Owls Glaucidium passerinum in old-growth forests of the southern French Prealps. - Journal of Ornithology 157(1): 333-342.

BAUMgaRT W. 1987: Observations of rare and protected birds in Bulgaria. - Ornithological Information Bull. 21-22: 10-15. [In Bulgarian.]

Beron P. 2002: On some owls (Aves: Strigidae) in high parts of Pirin (SW Bulgaria) and their parasitic flies (Diptera: Hippoboscidae). - Historia Naturalis Bulgarica 15: 147-149.

Boev Z., Gerasimov G. \& Nikolov S. 2007: Capercaillie (Tetrao urogallus). - In: Iankov P. Atlas of the breeding birds in Bulgaria. BSPB, Sofia.

Butiev V., Zubkov N., Ivanchev V., Koblik E., Kovshar A., Kotyukov Y., Lyuleeva D., Nazarov Y., Nechaev V., Priklonskyi S., Pukinskyi Y., Rustamov A., Sorokin A. \& Freedman V. 2005: Birds of Russia and neighboring regions: Strigiformes, Caprimulgiformes, Apodiformes, Coraciiformes, Upupiformes, Piciformes. - KMK, RAN, Moscow.

Castro A., Munoz A. \& Real R. 2008: Modelling the spatial distribution of the Tengmalm's owl Aegolius funereus in its Southwestern Palaeartic limit (NE Spain). - Ardeola 55 (1): 71-85.

Czeszczewik D., Walankiewicz W., Mitrus C., Tumiel T., Stanski T., Sahel M. \& BednarczyK G. 2013: Importance of dead wood resources for woodpeckers in coniferous stands of the Białowieża Forest. - Bird Conservation International 23(4): 414-425.

Cramp S. (Ed.) 1985: Handbook of the Birds of Europe, the
Middle East and North Africa. Vol IV. Terns to Woodpeckers. Oxford University Press. Oxford, New York.

Cramp S. \& Simmons K. (Eds.) 1980: Handbook of the Birds of Europe, the Middle East and North Africa. Vol II. Hawks to Bustards. - Oxford University Press. Oxford, New York.

Coppes J., Ehrlacher J., Thiel D., Suchant R. \& BrauNISCH V. 2017: Outdoor recreation causes effective habitat reduction in Capercaillie Tetrao urogallus: a major threat for geographically restricted populations. - Journal of Avian Biology 48(12): 1583-1594.

Dalmau J., Marine R., Martinez-Vidal R., Canut J. \& Garcia-Ferre D. 1998:

El mussol de Tengmalm Aegolius funereus a la Cerdanya, el Pallars Sobirà i el Principat d'Andorra: noves localitats de cant i reproducció (1990-1998). - Anuari D’Ornitologia de Catalunya: 306-314.

Danko Š., Darolova A. \& Krištin A. (eds.) 2002: Birds distribution in Slovakia. - Veda. Bratislava.

DENAC D. 2006: Intraspecific Exploitation Competition as Cause for Density Dependent Breeding Success in the White Stork. - Waterbirds: The International Journal of Waterbird Biology 29(3): 391-394.

Freeman B., Lee-Yaw J., Sunday J. \& Hargreaves A. 2018: Expanding, shifting and shrinking: The impact of global warming on species' elevational distributions. - Global Ecology and Biogeography 11: $1268-1276$.

Gasteratos I., Fondoulakou Z., Alivizatos C., Navarrete E., Sidiropoulos L., Shogolev E. \& PanagioTOPOULOU M. 2015: Habitat and distribution of Pygmy Owl in Greece. - 13th International Congress of Zoogeography and Ecology of Greece and Adjacent Regions, 7-11.10. 2015. Irakleio. Poster.

Gerdzhikov K., Georgiev K., Plachiyski D., Zlatanov T. \& Shurulinkov P. 2018: Habitat Requirements of the White-backed Woodpecker Dendrocopos leucotos lilfordi (Sharpe \& Dresser, 1871) (Piciformes: Picidae) in Strandzha Mountain, Bulgaria. - Acta Zoologica Bulgarica 70(4): 527-534.

Gill J. , Norris K. \& Sutherland W. 2001: Why behavioural responses may not reflect the population consequences of human disturbance. - Biological Conservation 97: 265-268.

Glutz Von Blotzheim U. \& Bauer K. 1980: Handbuch der Vogel Mitteleuropas. vol. 9. - Aula Verlag, Wiesbaden.

Gorman G. (Ed.) 2004: Woodpeckers of Europe. — Bruce 
Coleman Books, Chalfont St.Peter, UK.

Hakkarainen H., Korpimäki E., LaAksonen T., Nikula A. \& SuORSA P. 2007: Survival of male Tengmalm's owls increases with cover of old forest in their territory. - Oecologia 155: 479-486.

Imbeau L. \& Desrochers A. 2002: Area sensitivity and edge avoidance: the case of the Threetoed Woodpecker (Picoides tridactylus) in a managed forest. — Forest Ecology and Management 164: 249-256.

Jonieniaux A. \& Durand G. 1987: Forest management and population ecology of Tengmalm's Owl. - Rev. Ecol. Terre et la Vie, Supplement 4: 84-87.

KALlander H. 1964: Irruption in 1958 of Tengmalm's Owl in 1958 (Aegolius funereus) into Cenral Sweden and some aspects on the distribution of the species in Sweden. - Var Fagelward 19: 119-135.

KORŇAN M. 2006: Evaluation of silvicultural practices impact on forest bird assemblages: A review. Tichodroma 18: 111-128.

KORŇAN M. 2016: Effects of building ski resorts and winter recreation on birds: a review - Tichodroma 28: 86-96.

KORŇAN M. 2020: Potential negative effects of construction of a high-mountain ski resort in the High Tatras, Slovakia, on breeding bird assemblages. - Community Ecology 21: 213-226.

KorPIMÄKI E. 1981: On the ecology and biology of Tengmalm's Owl (Aegolius funereus) in Southern Ostrobothnia and Suomenselkä western Finland. Dissert. Thesis Oulu University.

KorPIMÄKI E. 1994: Rapid or delayed tracking of multiannual vole cycles by avian predators? - Journal of Animal Ecology 63: 619-628.

KorpimäKi E. \& Norrdahl K. 1989: Predation of Tengmalm's Owls (Aegolius funereus): numerical responses, functional responses and dampening impact on population implications of microtines. Oikos 54: 154-164.

LENZ M. 1967: Verbreitung des Sperlingskauzes (Glaucidium passerinum) im Rachelgebiet (Bayerischer Wald). — Ornittologische Mitteilungen 19 (10): 213-216.

Mestecaneanu A. \& Mestecaneuanu F. 2019: Some observations regarding the Eurasian Pygmy Owl (Glaucidium passerinum Linnaeus, 1758) from the Fagarasm Iezer-Papusa and Leaota Mountains (Southern Carpathians, Romania). - Muzeul Oltenei Craiova. Oltenia. Studii si comunicari. Stiintele Naturii 35 (1): 145-154.
Moss R., Leckie F., Biggins A., Poole T., Baines D. \&

KoRTLAND K. 2014: Impacts of human disturbance on capercaillie Tetrao urogallus distribution and demography in Scottish woodland. - Wildlife Biology 20: 1-18.

Mysterud I. 2016: Range Extensions of Some Boreal Owl Species: Comments on Snow Cover, Ice Crusts, and Climate Change. - Arctic, Antarctic and Alpine Research 48 (1): 213-219. NAnkinov D. 2002: Three-toed Woodpecker (Picoides tridactylus): Glacial Relict in Bulgaria. Journal of Balkan Ecology 5 (3): 237-243.

National Park Pirin Management Plan 2004-2013. 2014: Ministry of Environment and Waters, Bulgarian Biodiversity Foundation, Bansko.

NATURA 2000 SPA “PIRIN" - STANDARD FORM. http:// natura2000.moew.government.bg/PublicDownloads/ Auto/PS SPA/BG0000209/BG0000209 PS 16.pdf

Nikolov B., Hristov I., Shurulinkov P., Nikolov I., Rogev A., Dutsov A. \& Stanchev R. 2001: New data on some poorly studied forest species of owls (Strix uralensis, Glaucidium passerinum, Aegolius funereus) in Bulgaria. — Forest Science 1/2: 75-86.

Nikolov B., Shurulinkov P., Ralev A., Hristov K. \& Dimov P. 2010: Mapping of the sites and populations estimates of rare and protected species of birds ( $T$. urogallus, B. bonasia, A. funereus, G. passerinum, P. tridactylus, D. martius, P. canus, D. leucotus, $S$. rusticola) in the scope of the planned ski-zones: 1) Panichiste-Ezerata-Kabul; Iskrovete -Govedartsi Malyovitsa; Kartala; Super Borovetz 2) Super Perelik \& Syutka. - Technical report, Bulgarian Biodiversity Foundation, Sofia.

Nikolov B., Shurulinkov P. \& Hristova-Nikolova I. 2011: Bird density and species composition in Sweet Chestnut (Castanea sativa) dominated forests in the Bulgarian part of Belasitsa Mountain. In: Zlatanov T., Velichkov I. \& Nikolov B. eds "State and prospects of the Castanea sativa population in Belasitsa Mountain: climate change adaptation; maintenance of biodiversity and sustainable ecosystem management". - Project BG 0031 EEA report, Forest Research Institute, Sofia, Bulgaria.

Nikolov S. 2003: New locality in unusual habitat of Tengmalm's Owl (Aegolius funereus) in Bulgaria. Buteo 13: 89-93.

Nikolov S. 2005: Breeding birds in Macedonian Pine, Pinus peuce forests: species composition and status 
in the Pirin National Park, Bulgaria. - Ciconia 14: 26-34.

NikoLov S. 2013: Bird assemblages in naturally fragmented upland forests in Pirin National Park, Bulgaria. - Acta Zoologica Bulgarica 65: 493-504.

Pačenovský S. \& Shurulinkov P. 2008: Latest data on distribution of the Pigmy Owl (Glaucidium passerinum) in Bulgaria and Slovakia including population density comparison. - Slovak Raptor Journal 2: 91-106.

Pakkala T., Hansk I. \& Tompro E. 2002: Spatial ecology of the three-toed woodpecker in managed forest landscapes. - Silva Fennica 36: 279-288.

Plachiyski D., Nikolov S., Popgeorgiev G., Avramov S., Valchev K., Shurulinkov P., Angelova K. \& Daskalova G. 2015: Action Plan for the Capercaillie (Tetrao urogallus) in Bulgaria for the period 2016-2025. - Bulgarian Biodiversity Foundation \& Ministry of Environment and Waters, Sofia. .

Plachiyski D., Popgeorgiev G., Avramov S. \& Boev Z. 2018: The Balkan Capercaillie Tetrao urogallus rudolfi Dombrowski, 1912 (Galliformes: Phasianidae): Distribution History and Current Status in Bulgaria. - Acta Zoologica Bulgarica 70: 101-111.

Project №DIR5113325 Management Plan of Pirin NP 2014-2023.

Rajkovic D., Grujic D., Novcic R. \& Miric R. 2013: Population of Tengmalm's Owl Aegolius funereus in Kopaonik National Park (Central Serbia). — Acrocephalus 34: 27-32.

RAŠSASKI J. \& GAVRILOV T. 1983: Clamator glandarius I Glaucidium passerinum u Crnoj Gori. — Larus 33-35: 206-207.

Rosner S., Mussard-Forster E., LorenC T. \& Muller J. 2014: Recreation shapes a "landscape of fear" for a threatened forest bird species in Central Europe. Landscape Ecology 29: 55-66.

SANiga M. 2011: Why the Capercaillie population (Tetrao urogallus $\mathrm{L}$.) in mountain forests in the Central Slovakia decline? - Folia Oecologica 38: 110-117.

Saurola P. \& Francis C. 2004: Estimating population dynamics and dispersal distances of owls from nationally coordinated ringing data in Finland. - Animal Biodiversity and Conservation 27: 403-415.

SсHÖNN S. 1980: Der Sperlingskauz Glaucidium passerinum passerinum. - Die Neue Brehm Bücherei. Wittenberg. Lutherstadt.

ScherZINGER W. 1974: Zur Ökologie des Sperlingskauzes
Glaucidium passerinum im Nationalpark Bayerischer Wald. - Anzeiger der Ornithologischen Gesellschaft in Bayern 13: 121- 156.

Shurulinkov P. \& Stoyanov G. 2003: The birds of "Pirin" National Park. - Pp.: 54-66. In: Management Plan of Pirin National Park, 2004-2013. - Bulgarian Biodiversity Foundation, Sofia. (in Bulgarian)

Shurulinkov P., Stoyanov G., Tzvetkov P., Vulchev K., Kolchagov R.\& Ilieva M. 2003: Distribution and abundance of Tengmalm's Owl Aegolius funereus on Mount Pirin, south-west Bulgaria. - Sandgrouse 25: 103-117.

Shurulinkov P., Stoyanov G., Komitov E., Daskalova G. \& RALEV A. 2012: Contribution to the knowledge on distribution, number and habitat preferences of rare and endangered birds in Western Rhodopes Mts. Southern Bulgaria. Strigiformes and Piciformes. Acta zoologica bulgarica 64: 43-56.

Simeonov S. 1975: Ornithocenological analysis of the breeding avifauna of the monospecific coniferous forests in Bulgaria. - Ekologia 1: 55-63. (In Bulgarian).

Sisk T. D. \& BAtTin J. 2002: Habitat edges and avian ecology: geographic patterns and insights for western landscapes. - Studies in Avian Biology 25: 30-48.

ŠOtNÁR K., OBUCH J., PAČENOVSKÝ S. \& JARČUŠKa B. 2020: Spatial distribution of four sympatric owl species in Carpathian montane forests. - Raptor Journal 14: DOI: $10.2478 /$ srj20200002

Spiridonov J., Nikolov B. \& Shurulinkov P. 2015a: Pygmy Owl (Glaucidium passerinum). - Pp.: 191. In: Golemanski V. (Ed.) 2015: Red Data Book of Bulgaria. - BAS \& MOEW, Sofia.

Spiridonov J., Shurulinkov P. \& Zlatanov T. 2015b: Three-toed Woodpecker (Picoides tridctylus). - Pp.: 195. In: Golemanski V. (Ed.) 2015: Red Data Book of Bulgaria. - BAS \& MOEW, Sofia.

Stenseth N. \& Ims R. (eds.) 1993: The Biology of Lemmings. - London Academic Press, Linnean Society Symposium Series.

Summers R., McFarlane J. \& Pearce-Higgins J. 2007: Measuring Avoidance by Capercaillies Tetrao urogallus of Woodland Close to Tracks. - Wildlife Biology 13: 19-27.

Thiel D., Eiermann S., Palme R., Braunisch V. \& Jenni L. 2008: Ski tourism affects habitat use and evokes a physiological stress response in Capercaillie Tetrao urogallus: a new methodological approach. - Journal of Applied Ecology 45: 845-853. 
Trautman S. 2018: Climate change impacts on bird species. - Pp.: 217-234. In: Tietze D. (Ed.) Bird species. Fascinating Life Science. - Springer, Cham.

Watson A. \& Moss R. 2008: Grouse. The Natural History of British and Irish Species. - Collins, London.

Wesolowski T., Czeszczewik D. \& Rowinski P. 2005: Effects of forest management on Three-toed Woodpecker Picoides tridactylus distribution in the Białowieża Forest (NE Poland): conservation implications. - Acta Ornithologica 40 (1): 53-60.

VRezec A. 2003: Breeding density and altitudinal distribution of the Ural, Tawny and Boreal Owls in North
Dinaric Alps (central Slovenia). - Journal of Raptor Research 37 (1): 55-62.

VAlCHEV K. 2014: General report on the status of the population of Capercaillie (Tetrao urogallus L.) on the territory of "Pirin" National Park. — Bioresearch, Sofia. (In Bulgarian).

ZÁrybnická M., Riegert J., BejČek V., Sedláček F., ŠŤastný K., ŠindeláŘ J., Heroldová M., Vilímová J. \& ZIMA J. 2017: Long-term changes of small mammal communities in heterogenous landscapes of Central Europe. - European Journal of Wildlife Research 63: 89 .

Received: 26. 1. 2021

Accepted: 27. 3. 2021

Online: 15. 6. 2021 